\title{
Mapping
}

European security after Kosovo

\author{
edited by \\ Peter van Ham \\ and Sergei Medvedev
}




\section{Mapping European security after Kosovo}

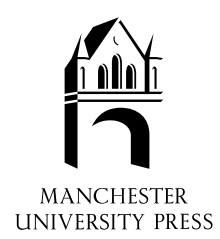


Peter van Ham and Sergei Medvedev - 9781526137517 Downloaded from manchesterhive.com at 04/26/2023 08:25:26AM 


\section{Mapping European security after Kosovo}

edited by

Peter van Ham and Sergei Medvedev

Manchester University Press

Manchester 
Copyright (C) Manchester University Press 2002

While copyright in the volume as a whole is vested in Manchester University Press, copyright in individual chapters belongs to their respective authors, and no chapter may be reproduced wholly or in part without the express permission in writing of both author and publisher.

Published by Manchester University Press

Altrincham Street, Manchester M1 7JA, UK

www.manchesteruniversitypress.co.uk

British Library Cataloguing-in-Publication Data

A catalogue record for this book is available from the British Library

Library of Congress Cataloging-in-Publication Data applied for

ISBN 0719062403 hardback

First published 2002

$100908070605040302 \quad 10987654321$

The publisher has no responsibility for the persistence or accuracy of URLs for any external or third-party internet websites referred to in this book, and does not guarantee that any content on such websites is, or will remain, accurate or appropriate.

Typeset in Times

by Graphicraft Limited, Hong Kong 